\title{
Microbial community associated with Baicalian crustacea near gas-oil deepwater discharges
}

LIMNOLOGY FRESHWATER

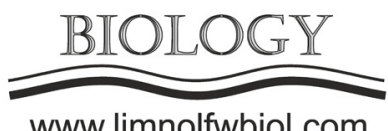

\author{
Khalzov I.A.*, Bukin S.V., Chernitsyna S.M., Zakharenko A.S., Galachyants Yu.P., \\ Sitnikova T.Ya., Zemskaya T.I.
}

Limnological Institute, Siberian Branch of the Russian Academy of Sciences, 3 Ulan-Batorskaya Street, Irkutsk 664033, Russia

\begin{abstract}
Using scanning electron microscopy we investigated the epibiotic associations of peritrichial sessile ciliates of the Lagenophrys (Ciliophora: Lagenoprydae) and prokaryotes of various morphologies on the surface of endemic amphipods Macropereiopus florii (Dybowsky 1874) and ostracods Candona (Candonidae). We noted biofouling and mineralization in the areas of formation of a bacterial biofilm, which includes $\mathrm{Fe}, \mathrm{P}$, and other elements. High-throughput sequencing on the Illumina MiSeq platform showed the presence of such bacterial phyla as Actinobacteria, Gracilibacteria, Cyanobacteria, Proteobacteria, Bacteroidetes in the ostracod microbiome, of which the latter two were dominant. Sequence analysis of the 16S rRNA gene fragment showed epibiotic microorganisms that are related to the colorless sulfur bacteria Thiothrix sp. More than $50 \%$ of all sequences were attributed to endosymbiont bacteria of the genus Rickettsia, and the presence of endosymbionts of the genus Ca. Cardinium was shown for the first time for Baikal ostracods.
\end{abstract}

Keywords: epibiosys, methane seep, Baikal, crustacea, microbial ecology

Symbioses play a key role in life and evolution on our planet. New symbiotic associations of aquatic ecosystems can significantly expand the capabilities of partners involved in these relationships. This leads to important ecological changes in habitats, contributes to biodiversity and high productivity (Cavanaugh et al., 2005; Gast et al., 2009). In the zones affected by deep-sea hydrothermal springs and methane seeps, as well as in coastal zones saturated with organic matter, invertebrates live, which often are in symbiosis with chemolithoautotrophic bacteria. In such communities, animals associated with prokaryotes, or symbiotrophs, are dominant in the overwhelming majority of cases (Carman and Dobbs, 1997; Van Dover et al., 2002).

Epibiotic organisms, such as prokaryotes, protozoa, microscopic algae and fungi, can enter into mutually beneficial relationships with basibionts, but in most cases these associations are determined as commensalism. Nevertheless, some studies suggest an indirect effect of epibionts on their crustacean hosts (Wahl, 2008).

Methane and oil seeps, mud volcanoes and outcrops of highly mineralized fluids existing on the bottom of Lake Baikal are associated with biological communities of various compositions. They include a wide range of organisms from bacteria and microscopic fungi to invertebrates (Namsaraev et al., 2002; Zemskaya et al., 2012).
The aim of our research was to study the probable ways of involving carbon of different origin (for example, methane) and other biogenic elements in food webs using integral methods (electron microscopy, high-throughput sequencing). One of the mechanisms responsible for the entrainment of methane carbon may be symbiotic relationships between aquatic invertebrates and microbial communities that include methanotrophs (Goffredi et al., 2008).

In the area of the hydrothermal spring in Frolikha Bay, we were the first to find epibiotic associations of ciliates Lagenophrys sp. and prokaryotes on the surface of the cuticle of Baikal endemic amphipods (Khalzov et al., 2018). In the areas of the Goloustnoye methane seep, samples of ostracods Candona sp. were taken, on the surface of which shells of Lagenophrys sp. were also found, forming a consortium with microorganisms. The study using scanning electron microscopy showed different morphology of cells of microorganisms, and also revealed the presence of a special mineral substance on which bacteria are located.

In this study bacterial fouling of ostracod valve was mainly located near ciliate loricae. The area of the observed bacterial biofilms occupied $\sim 12 \%$ of the valve surface. The density of bacteria in the biofilm formed by these bacteria was approximately 20 cells per $100 \mu \mathrm{m}^{2}$. The surface of the ostracod valves had many objects of non-biological nature: mineral particles and crystals of 
various morphology localized between bacterial cells. Elemental analysis of mineral substance revealed the presence of $\mathrm{Si}, \mathrm{Al}, \mathrm{P}, \mathrm{S}, \mathrm{Ca}$, and $\mathrm{Fe}$.

High-throughput sequencing on the Illumina MiSeq platform showed the presence of such bacterial phyla as Actinobacteria, Gracilibacteria, Cyanobacteria, Proteobacteria, Bacteroidetes in the ostracod microbiome, of which the latter two were dominant. The main part of the bacteria associated with ostracods was represented by the phylum Proteobacteria (77\%), among which representatives of the class Alphaproteobacteria dominated (54\%). Most of the sequences of this class were assigned to the genus Rickettsia (50\%).

The Gammaproteobacteria class accounted for $22 \%$ of the total number of sequences. Only $11 \%$ of all sequences belonged to the family Methylomonaceae, and about $7 \%$ were members of the Thiotrichaceae family, resembling the sulfur bacteria of the Thiothrix genus.

Representatives of the phylum Bactroidetes accounted for $22 \%$ of the total number of OTUs, $17 \%$ were attributed to the order Flavobacteriales. Among them, the majority of representatives belonged to the unclassified, only a small part $(0.8 \%)$ belonged to the Flavobacteraceae family.

For the first time in the microbiome of Baikal ostracods, they were found in sequences belonging to endosymbionts of theorders Rickettsiales and Holosporales. It is quite probable that the representatives of Rickettsia we identified may be endosymbionts of ostracods. The presence of rickettsia in freshwater ostracods has been shown for the first time. Representatives of the genus Cardinium for Baikal species of crustaceans were also not previously noted.

\section{Acknowledgements}

This work was conducted within the framework of the State Task (project No. 0345-2019-0007 (AAAA-A16-116122110064-7) and mol-a RFBR grant No 18-34-00442. This study was carried out using computational resources of the HPC-cluster «Akademik V.M. Matrosov» of Irkutsk Supercomputer Center of
SB RAS and equipment of Core Centrum 'Genomic Technologies, Proteomics and Cell Biology’ in ARRIAM.

\section{References}

CarmanK.R.,DobbsF.C.1997.Epibioticmicroorganismson copepods and other marine crustaceans. Microscopy Research and Technique 37: 116-135. DOI: 10.1002/(SICI)10970029(19970415)37:2<116::AID-JEMT2 > 3.0.CO;2-M

Cavanaugh C.M., McKiness Z.P., Newton I.L.G. et al. 2006. Marine chemosynthetic symbioses. In: Dworkin M., Falkow S., Rosenberg E. et al. (Eds.), The Prokaryotes. New York, pp. 457-507. DOI: 10.1007/0-387-30741-9_18

Gast R.J., Sanders R.W., Caron D.A. 2009. Ecological strategies of protists and their symbiotic relationships with prokaryotic microbes. Trends in Microbiology 17: 563-569. DOI: 10.1016/j.tim.2009.09.001

Goffredi S.K., Wilpiszeski R., Lee R. et al. 2008. Temporal evolution of methane cycling and phylogenetic diversity of archaea in sediments from a deep-sea whale-fall in Monterey Canyon, California. The ISME Journal 2: 204-220. DOI: 10.1038/ismej.2007.103

Khalzov I.A., Mekhanikova I.V., Sitnikova T.Y. 2018. First data on ectosymbiotic consortia of infusoria and prokaryotes associated with amphipods inhabiting the Frolikha underwater hydrothermal vent, Lake Baikal. Zoologicheskii Zhurnal [Journal of Zoology] 97: 1525-1530. DOI: 10.1134/ S0044513418120073 (in Russian)

Namsaraev B.B., Zemskaya T.I., Dagurova O.P. et al. 2002. Bacterial communities of the bottom sediments near a hydrothermal source in Frolikha Bay (northern Baikal). Geologiya i Geofizika [Geology and Geophysics] 43: 644-647. (in Russian)

Van Dover C.L., German C.R., Speer K.G. et al. 2002. Evolution and biogeography of deep-sea vent and seep invertebrates. Science 295: 1253-1257. DOI: 10.1126/ science.1067361

Wahl M. 2008. Ecological lever and interface ecology epibiosis modulates the interactions between host and environment. Biofouling 24: 427-438. DOI: 10.1080/08927010802339772

Zemskaya T.I., Sitnikova T.Y., Kiyashko et al. 2012. Faunal communities at sites of gas-and oil-bearing fluids in Lake Baikal. Geo-Marine Letters 32: 437-451. DOI: 10.1007/ s00367-012-0297-8 